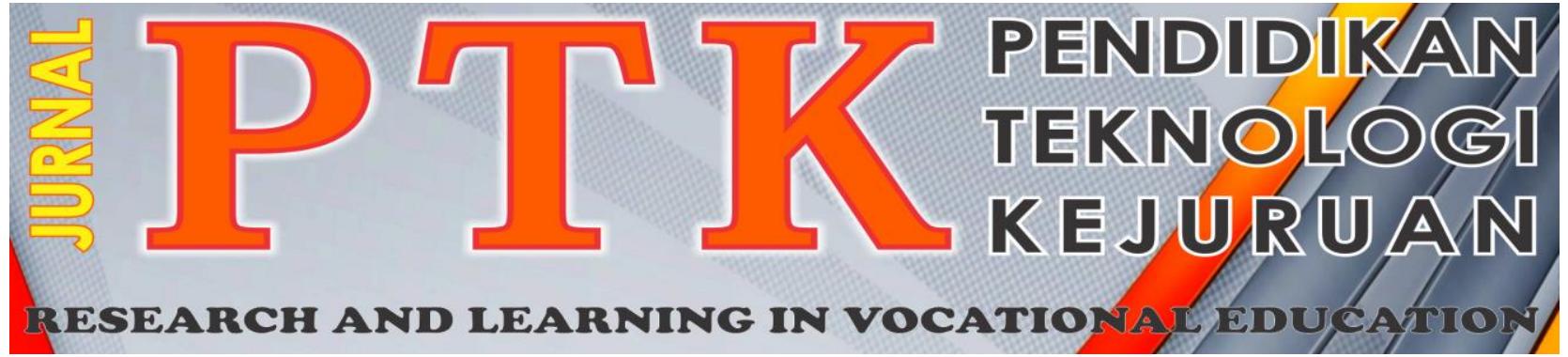

Vol. 2, No. 2 Mei 2019

P-ISSN: 2621-3273

E-ISSN: 2621-1548

\title{
ESTIMASI PERMINTAAN AIR MINUM DALAM KEMASAN AYIA CUP 240 ML PADA PT. GUNUNG NAGA MAS
}

\author{
Riko Ervil ${ }^{1}$, Mela Rosalina ${ }^{2}$ \\ ${ }^{1,2}$ Teknik Industri, Sekolah Tinggi Teknologi Industri (STTIND) Padang \\ ${ }^{*}$ Corresponding author, e-mail: rikoervil@ @stind.ac.id
}

\begin{abstract}
Abstrak: Permintaan konsumen sangat penting dalam kegiatan industri pada saat ini, karena proses produksi baru akan berjalan apabila ada permintaan dari konsumen. Permasalahan yang ada pada PT Gunung Naga Mas adalah perusahaan memproduksi barang tanpa mempertimbangkan permintaan pasar, sehingga mengakibatkan bertambahnya biaya penyimpanan dan juga barang yang lama disimpan akan mengalami kerusakan. Untuk itu perlu dilakukannya estimasi permintaan dengan metode Trend linear, Trend kuadratik dan Trend eksponensial. Dari tujuan penelitian dapat ditarik kesimpulan bahwa metode yang paling efektif untuk mengestimasi permintaan air minum dalam kemasan cup $240 \mathrm{ml}$ pada PT. Gunung Naga Mas yaitu metode trend linear dengan nilai MSE sebesar 544.291.863 dan estimasi permintaan produk air minum dalam kemasan cup $240 \mathrm{ml}$ pada PT Gunung Naga Mas pada tahun 2018 yaitu totalnya sebesar 1.918 .768 dus. Sehingga Perusahaan perlu menyesuaikan kapasitas produksi pada tahun 2018.
\end{abstract}

Kata kunci : Estiamsi,Trend linear, MSE.

Abstract: Consumer demand is very important in industrial activities at this time, because the new production process will run if there is demand from consumers. The problem that exists at PT Gunung Naga Mas is that the company produces goods without considering market demand, resulting in increased storage costs and also items that are long stored will be damaged. For this reason, it is necessary to forecast demand with linear trend methods, quadratic trends and exponential trends. From the purpose of the study it can be concluded that the most effective method for predicting demand for drinking water in $240 \mathrm{ml}$ cup packaging at PT. Gunung Naga Mas is a linear trend method with MSE value of 544,291,863 and forecast demand for drinking water products in $240 \mathrm{ml}$ cup packaging at PT Gunung Naga Mas in 2018 which is a total of 1,918,768 boxes. So the Company needs to adjust production capacity in 2018.

Keywords: Forecasting, Linear Trend, MSE

\section{PENDAHULUAN}

Setiap perusahaan baik industri manufaktur maupun jasa pasti memiliki visi dan misi kedepannya untuk terus bertahan di tengah persaingan dengan perusahaan lain. Oleh karena itu semua perusahaan dituntut untuk memperkirakan masa depan usahanya. Salah satunya yaitu estimasi permintaan, proses produksi baru akan berjalan apabila ada permintaan dari konsumen. Estimasi bertujuan dalam pengambilan keputusan oleh seorang manajer secara tepat untuk menentukan nasib suatu perusahaan di masa yang akan datang. Untuk mengetahui berapa permintaan periode berikutnya dan berapa jumlah produksi yang harus dikerjakan oleh suatu perusahaan maka seorang manajer harus dapat mengestimasi permintaan atas produk yang dihasilkannya untuk periode berikutnya.

Estimasi (forecasting) adalah seni dan ilmu untuk memperkirakan kejadian di masa depan. Hal ini dapat dilakukan dengan melibatkan pengambilan data historis dan memproyeksikannya ke masa akan datang dengan bentuk suatu model matematis. Hal ini bisa juga merupakan prediksi intuisi yang bersifat subjektif. Hal ini dapat dilakukan dengan menggunakan kombinasi model matematis yang disesuaikan dengan pertimbangan yang baik dari seorang manajer (Heizer dan Render, 2011). 
PT. Gunung Naga Mas merupakan perusahaan yang bergerak di bidang pengolahan air minum dalam kemasan dengan merk AYIA. Perusahaan ini didirikan pada tanggal 11 juli 2012 sampai saat ini telah memproduksi beberapa jenis varian air minum kemasan antara lain ayia cup $240 \mathrm{ml}$, ayia botol 380 $\mathrm{ml}$, ayia botol $660 \mathrm{ml}$, ayia botol $1500 \mathrm{ml}$, dan ayia galon. Untuk area penjualan ayia telah tersebar di berbagai wilayah dalam provinsi sumatera barat antara lain kota Padang, kab. Pariaman, solok, kab. Solok selatan, Pasaman barat, kab. Pesisir selatan. Ditambah beberapa diluar kota sumatera barat yaitu di Sungai Penuh, Kerinci. Permasalahan yang ada pada PT. Gunung Naga Mas adalah produksi yang dilakukan oleh perusahaan tidak mempertimbangkan permintaan pasar sehingga banyak barang jadi menumpuk di gudang. Apabila hal tersebut dibiarkan terus maka akan berakibat pada kerugian perusahaan seperti bertambahnya biaya penyimpanan dan kerusakan produk AMDK yang terlalu lama disimpan di gudang. Untuk meminimalisir kemungkinan-kemungkinan di atas dan untuk memenuhi kebutuhan pasar maka perusahaan PT. Gunung Naga Mas perlu melakukan estimasi permintaan untuk masa yang akan datang sehingga perusahaan dapat memproduksi barang sesuai dengan permintaan yang telah diramalkan. Dengan adanya Estimasi permintaan juga dapat membantu perusahaan dalam meminimalkan biaya produksi.

Tujuan penelitian ini adalah untuk mengetahui metode yang paling efektif untuk mengestimasi permintaan air minum dalam kemasan cup $240 \mathrm{ml}$ pada PT. Gunung Naga Mas dan Menghitung estimasi permintaan produk air minum dalam kemasan cup $240 \mathrm{ml}$ pada PT. Gunung Naga Mas pada tahun 2018 .

\section{METODE PENELITIAN}

Jenis penelitian yang dilakukan penulis adalah penelitian deskriptif kuantitatif yaitu pengolahan data yang berupa angka pada suatu perusahaan atau industri yang nantinya data akan dikumpulkan dan diolah sehingga memberikan informasi yang berguna dengan menggunakan perumusan matematika. Penelitian dilaksanakan di di PT. Gunung Naga Mas J1. Raya kuranji - Kampung Pinang Kav. 8, Kuranji, Kota Padang, Sumatera Barat. Sedangkan waktu penelitian dilaksanakan pada Bulan Desember 2017 sampai dengan Januari 2018.

Dalam penelitian ini data yang digunakan adalah data permintaan konsumen pada tahun 2016 dan 2017. Pengolahan data dilakukan dengan menentukan nilai Mean Square error (MSE) terkecil dari metode trend linear, trend kuadratik dan trend eksponensial pengujian verifikasi hasil estimasi terpilih menggunakan peta moving range, dan terakhir menghitung ramalan permintaan ayia cup $240 \mathrm{ml}$ untuk tahun 2018.

\section{HASIL DAN PEMBAHASAN}

Berikut merupakan data permintaan air minum dalam kemasan cup $240 \mathrm{ml}$ di PT.Gunung Mas:

Tabel 1. Data permintaan air minum dalam kemasan cup $240 \mathrm{ml}$

\begin{tabular}{|c|c|c|}
\hline \multirow[t]{2}{*}{ Bulan } & \multicolumn{2}{|c|}{$\begin{array}{c}\text { Jumlah } \\
\text { Permintaan ( Dus) }\end{array}$} \\
\hline & 2016 & 2017 \\
\hline Januari & 172.602 & 129.869 \\
\hline Februari & 143.826 & 180.051 \\
\hline Maret & 178.201 & 174.927 \\
\hline April & 132.341 & 145.321 \\
\hline Mei & 176.316 & 186.678 \\
\hline Juni & 141.267 & 130.148 \\
\hline Juli & 132.371 & 173.230 \\
\hline Agustus & 198.561 & 210.716 \\
\hline September & 175.269 & 161.014 \\
\hline Oktober & 172.621 & 146.705 \\
\hline November & 148.763 & 153.224 \\
\hline Desember & 130.458 & 128.549 \\
\hline
\end{tabular}

Dari tabel diatas dapat diketahui bahwa permintaan air minum dalam kemasan cup $240 \mathrm{ml}$ di PT. Gunung Naga Mas setiap bulan nya dari tahun 2016 sampai tahun 2017 terjadi kenaikan dan penurunan permintaan yang cukup signifikan terlihat dari rentang angka yang memiliki perbedaan yang jauh antara bulan satu dengan bulan lain.oleh karena itu perlu dilakukan penentuan estimasi terbaik agar dapat memprediksi jumlah yang harus diproduksi untuk tahun 2018 secara tepat.

\section{Pemilihan Metode Estimasi Terbaik}

\section{Metode estimasi Trend Linear}

Untuk menentukan estimasi dengan metode ini, maka digunakan rumus sebagai berikut:

Bentuk persamaannya : $y(t)=a+b t$

Keterangan :

$\mathrm{y}(\mathrm{t})=$ Variabel yang diprediksi $\mathrm{a}, \mathrm{b}=$

Parameter estimasi

$\mathrm{t}=$ Periode waktu

Berikut hasil perhitungan dengan menggunakan metode trend linear:

Tabel 2. Perhitungan estimasi metode trend Linear

Jurnal PTK: Research and Learning in Vocational Education 


\begin{tabular}{|c|c|c|c|c|}
\hline \multirow[b]{2}{*}{ No } & \multirow[b]{2}{*}{ Periode } & \multirow[b]{2}{*}{ Bulan } & $\begin{array}{c}\text { Ramalan } \\
\text { Permintaan }\end{array}$ & \multirow[t]{2}{*}{ Roundup } \\
\hline & & & (Dus) & \\
\hline 1 & 25 & Januari & 160450,6133 & 160451 \\
\hline 2 & 26 & Februari & 160349,9368 & 160350 \\
\hline 3 & 27 & Maret & 160249,2603 & 160250 \\
\hline 4 & 28 & April & 160148,5838 & 160149 \\
\hline 5 & 29 & Mei & 160047,9072 & 160048 \\
\hline 6 & 30 & Juni & 159947,2307 & 159948 \\
\hline 7 & 31 & Juli & 159846,5542 & 159847 \\
\hline 8 & 32 & Agustus & 159745,8777 & 159746 \\
\hline 9 & 33 & September & 159645,2012 & 159646 \\
\hline 10 & 34 & Oktober & 159544,5246 & 159545 \\
\hline 11 & 35 & November & 159443,8481 & 159444 \\
\hline 12 & 36 & Desember & 159343,1716 & 159344 \\
\hline & & & Total & 1918768 \\
\hline
\end{tabular}

Kemudian selanjutnya menghitung rata-rata kuadrat kesalahan ( Mean square error $=\mathrm{MSE}$ )

Tabel 3. Perhitungan galat metode estimasi Linie

\begin{tabular}{|c|c|c|c|c|}
\hline $\mathrm{t}$ & $\mathrm{y}$ & $\mathrm{y}^{\prime}$ & $\mathrm{e}$ & $\mathrm{e}^{\wedge}$ \\
\hline 1 & 172602 & 160450,61 & 12.151 & 147656198 \\
\hline 2 & 143826 & 160349,93 & -16.524 & 273040488 \\
\hline 3 & 178201 & 160249,26 & 17.952 & 322264959 \\
\hline 4 & 132341 & 160148,58 & -27.808 & 773261715 \\
\hline 5 & 176316 & 160047,90 & 16.268 & 264650842 \\
\hline 6 & 141267 & 159947,23 & -18.680 & 348951020 \\
\hline 7 & 132371 & 159846,55 & -27.476 & 754906079 \\
\hline 8 & 198561 & 159745,87 & 38.815 & 1506613721 \\
\hline 9 & 175269 & 159645,20 & 15.624 & 244103090 \\
\hline 10 & 172621 & 159544,52 & 13.076 & 170994208 \\
\hline 11 & 148763 & 159443,84 & -10.681 & 114080516 \\
\hline 12 & 130458 & 159343,17 & -28.885 & 834353138 \\
\hline 13 & 129869 & 159242,49 & -29.373 & 862802213 \\
\hline 14 & 180051 & 159141,81 & 20.909 & 437193869 \\
\hline 15 & 174927 & 159041,14 & 15.886 & 252360483 \\
\hline 16 & 145321 & 158940,46 & -13.619 & 185489841 \\
\hline 17 & 186678 & 158839,78 & 27.838 & 774965992 \\
\hline 18 & 130148 & 158739,11 & -28.591 & 817451712 \\
\hline 19 & 173230 & 158638,43 & 14.592 & 212913742 \\
\hline 20 & 210716 & 158537,75 & 52.178 & 2722568790 \\
\hline 21 & 161014 & 158437,08 & 2.577 & 6640502 \\
\hline 22 & 146705 & 158336,40 & -11.631 & 135289614 \\
\hline 23 & 153224 & 158235,73 & -5.012 & 25117436 \\
\hline 24 & 128549 & 158135,05 & -29.586 & 875334552 \\
\hline Total & & & & 13063004719 \\
\hline $\mathrm{MSE}=544.291 .863$ & & \\
\hline
\end{tabular}

Dari tabel perhitungan galat dapat diketahui nilai standar error untuk estimasi metode trend linear yaitu 544.291.863.

\section{Metode Estimasi Trend Kuadratik}

Untuk melakukan perhitunganmenggunakan metode ini digunakan rumus sebagai berikut: ( )

Keterangan : $\mathrm{y}(\mathrm{t})=$ Variabel yang diprediksi a,b,c $=$

Parameter estimasi

$$
\mathrm{t} \quad=\text { Periode waktu }
$$

Dari persamaan diatas maka perlu dicari nilai $a, b$ dan c menggunakan rumus seperti berikut ini:

$$
\begin{aligned}
& a=\frac{\sum Y-c \sum t^{2}}{n} \\
& b=\frac{\sum t Y}{\sum t^{2}} \\
& c=\frac{n \sum t^{2} Y-\sum t^{2} \sum Y}{n \sum t^{4}-\left(\sum t^{2}\right)^{2}}
\end{aligned}
$$

Hasil perhitungan dengan menggunakan metode trend kuadratik:

Tabel 4. Perhitungan estimasi metode trend kuadratik

\begin{tabular}{|c|c|c|c|c|c|c|c|}
\hline Periode & $\mathrm{t}$ & $\mathrm{t}^{\wedge} 2$ & $\mathrm{t}^{\wedge} 4$ & $\mathrm{y}$ & $\mathrm{t}^{\wedge} 2{ }^{*} \mathrm{y}$ & $\mathrm{t}^{*} \mathrm{y}$ & $\mathrm{y}^{\prime}$ \\
\hline 1 & 1 & 1 & 1 & 172602 & 172602 & 172602 & 3834164 \\
\hline 2 & 2 & 4 & 16 & 143826 & 575304 & 287652 & 3843872 \\
\hline 3 & 3 & 9 & 81 & 178201 & 1603809 & 534603 & 3853567 \\
\hline 4 & 4 & 16 & 256 & 132341 & 2117456 & 529364 & 3863247 \\
\hline 5 & 5 & 25 & 625 & 176316 & 4407900 & 881580 & 3872914 \\
\hline 6 & 6 & 36 & 1296 & 141267 & 5085612 & 847602 & 3882567 \\
\hline 7 & 7 & 49 & 2401 & 132371 & 6486179 & 926597 & 3892206 \\
\hline 8 & 8 & 64 & 4096 & 198561 & 12707904 & 8 & 3901831 \\
\hline
\end{tabular}

Tabel 5. Lanjutan perhitungan estimasi Metode trend kuadratik

\begin{tabular}{|c|c|c|c|c|c|c|c|}
\hline $\begin{array}{c}\text { Period } \\
\mathrm{e}\end{array}$ & $\mathrm{t}$ & $\mathrm{t}^{\wedge} 2$ & $\mathrm{t}^{\wedge} 4$ & $\mathrm{y}$ & $\mathrm{t}^{\wedge} 2 * \mathrm{y}$ & $\mathrm{t}^{*} \mathrm{y}$ & $\mathrm{y}^{\prime}$ \\
\hline 9 & 9 & 81 & 6561 & 17526 & 14196789 & 1577421 & 2594412 \\
\hline 10 & 10 & 100 & 10000 & 17262 & 17262100 & 1726210 & 2608876 \\
\hline 11 & 11 & 121 & 14641 & 14876 & 18000323 & 1636393 & 2623924 \\
\hline 12 & 12 & 144 & 20736 & 13045 & 18785952 & 1565496 & 2639554 \\
\hline 13 & 13 & 169 & 28561 & 12986 & 21947861 & 1688297 & 2655768 \\
\hline 14 & 14 & 196 & 38416 & 18005 & 35289996 & 2520714 & 2672566 \\
\hline 15 & 15 & 225 & 50625 & 17492 & 39358575 & 2623905 & 2689946 \\
\hline 16 & 16 & 256 & 65536 & 14532 & 37202176 & 2325136 & 2707910 \\
\hline 17 & 17 & 289 & 83521 & 18667 & 53949942 & 3173526 & 2726457 \\
\hline 18 & 18 & 324 & 10497 & 13014 & 42167952 & 2342664 & 2745587 \\
\hline 19 & 19 & 361 & 13032 & 17323 & 62536030 & 3291370 & 2765301 \\
\hline 20 & 20 & 400 & 16000 & 21071 & 84286400 & 4214320 & 2785598 \\
\hline 21 & 21 & 441 & 19448 & 16101 & 71007174 & 3381294 & 2806478 \\
\hline 22 & 22 & 484 & 23425 & 14670 & 71005220 & 3227510 & 2827941 \\
\hline 23 & 23 & 529 & 27984 & 15322 & 81055496 & 3524152 & 2849988 \\
\hline 24 & 24 & 576 & 33177 & 12854 & 74044224 & 3085176 & 2872618 \\
\hline \multirow{2}{*}{ Total } & 264 & 4696 & 17542 & 254754 & 74209621 & 4190358 & \\
\cline { 2 - 3 } & & & & & & \\
\end{tabular}

Kemudian selanjutnya menghitung rata-rata kuadrat kesalahan ( Mean square error $=$ MSE) pada estimasi metode trend kuadratik sebagai berikut: 
Tabel 6. Perhitungan galat metode estimasi Kuadratik

\begin{tabular}{|c|c|c|c|c|}
\hline $\mathrm{t}$ & y & $\mathrm{y}^{\prime}$ & $\mathrm{e}$ & $\mathrm{e}^{\wedge} 2$ \\
\hline 1 & 172602 & 3834164 & -3661562 & $\begin{array}{c}1340703743466 \\
5\end{array}$ \\
\hline 2 & 143826 & 3843872 & -3700046 & \begin{tabular}{|c|}
1369034316621 \\
3 \\
\end{tabular} \\
\hline 3 & 178201 & 3853567 & -3675366 & $\begin{array}{c}1350831330102 \\
9\end{array}$ \\
\hline 4 & 132341 & 3863247 & -3730906 & $\begin{array}{c}1391966143329 \\
0 \\
\end{array}$ \\
\hline 5 & 176316 & 3872914 & -3696598 & $\begin{array}{c}1366483608727 \\
1\end{array}$ \\
\hline 6 & 141267 & 3882567 & -3741300 & \begin{tabular}{|c|}
1399732354825 \\
7 \\
\end{tabular} \\
\hline 7 & 132371 & 3892206 & -3759835 & $\begin{array}{c}1413635673120 \\
2 \\
\end{array}$ \\
\hline 8 & 198561 & 3901831 & -3703270 & $\begin{array}{c}1371420698983 \\
1 \\
\end{array}$ \\
\hline 9 & 175269 & 3911442 & -3736173 & $\begin{array}{c}1395898883346 \\
4\end{array}$ \\
\hline 10 & 172621 & 3921039 & -3748418 & \begin{tabular}{|c|}
1405064062983 \\
2 \\
\end{tabular} \\
\hline 11 & 148763 & 3930623 & -3781860 & \begin{tabular}{|c|}
1430246477367 \\
1 \\
\end{tabular} \\
\hline 12 & 130458 & 3940193 & -3809735 & \begin{tabular}{|c}
1451407814124 \\
1 \\
\end{tabular} \\
\hline 13 & 129869 & 3949748 & -3819879 & $\begin{array}{c}1459147935958 \\
1 \\
\end{array}$ \\
\hline 14 & 30051 & 3959290 & -3779239 & $\begin{array}{c}1428265107426 \\
9 \\
\end{array}$ \\
\hline 15 & 174927 & 3968819 & -3793892 & $\begin{array}{c}1439361362000 \\
0 \\
\end{array}$ \\
\hline 16 & 145321 & 3978333 & -3833012 & $\begin{array}{c}1469198024835 \\
9 \\
\end{array}$ \\
\hline 17 & 6678 & 3987833 & -3801155 & $\begin{array}{c}1444878187482 \\
7 \\
\end{array}$ \\
\hline 18 & 130148 & 3997320 & -3867172 & $\begin{array}{c}1495501860583 \\
0 \\
\end{array}$ \\
\hline 19 & 3230 & 4006793 & -3833563 & \begin{tabular}{|c|}
1469620251306 \\
3 \\
\end{tabular} \\
\hline 20 & 210716 & 4016252 & -3805536 & \begin{tabular}{|c|}
1448210054902 \\
5 \\
\end{tabular} \\
\hline 21 & 161014 & 4025697 & -3864683 & $\begin{array}{c}1493577110489 \\
6 \\
\end{array}$ \\
\hline 22 & 146705 & 4035128 & -3888423 & $\begin{array}{c}1511983113910 \\
7 \\
\end{array}$ \\
\hline 23 & 153224 & 4044545 & -3891321 & $\begin{array}{c}1514237930574 \\
4\end{array}$ \\
\hline 24 & 128549 & 4053948 & -3925399 & \begin{tabular}{|c|}
1540876114286 \\
7 \\
\end{tabular} \\
\hline To & & & & \begin{tabular}{|c}
3440128216075 \\
30 \\
\end{tabular} \\
\hline
\end{tabular}

$\mathrm{MSE}=\underline{344012821607530} 24$

$=14.333 .867 .566 .980$

Dari tabel perhitungan galat metode trend kuadratik di atas di dapat standar error nya yaitu 14.333.867.566.980.

\section{Metode Estimasi Trend Eksponensial}

Dalam melakukan perhitungan menggunakan metode ini digunakan persamaan sebagai berikut: Keterangan :

$\mathrm{y}(\mathrm{t})=$ Variabel yang diprediksi $\mathrm{a}, \mathrm{b}=$

Parameter estimasi $\mathrm{t}=$ Periode waktu

Dimana untuk mencari nilai a dan b menggunakan rumus dibawah ini:

$$
\begin{aligned}
& \Rightarrow a=\text { antilog }\left[\frac{\sum \log Y}{n}\right] \\
& \Rightarrow b=\text { antilog }\left[\frac{\sum t \log Y}{\sum t^{2}}\right]
\end{aligned}
$$

Hasil perhitungan dengan menggunakan metode trend eksponensial:

Tabel 7. Perhitungan estimasi Metode Trend Eksponensial

\begin{tabular}{|c|c|c|c|c|c|c|}
\hline Periode & $\mathrm{t}$ & $\mathrm{t}^{\wedge} 2$ & $\mathrm{y}$ & $\log \mathrm{y}$ & $\mathrm{t} * \log \mathrm{y}$ & $\mathrm{y}^{\prime}$ \\
\hline 1 & 1 & 1 & 172602 & $\begin{array}{c}5,2370 \\
5\end{array}$ & 5,23705 & 327880 \\
\hline 2 & 2 & 4 & 143826 & $\begin{array}{c}5,1578 \\
4\end{array}$ & 10,3157 & 682102 \\
\hline 3 & 3 & 9 & 178201 & $\begin{array}{c}5,2509 \\
1\end{array}$ & 15,7527 & 1419006 \\
\hline 4 & 4 & 16 & 132341 & $\begin{array}{c}5,1216 \\
9\end{array}$ & 20,4868 & 2952018 \\
\hline 5 & 5 & 25 & 176316 & $\begin{array}{c}5,2462 \\
9\end{array}$ & 26,2315 & 6141207 \\
\hline 6 & 6 & 36 & 141267 & 4 & 30,9002 & 12775813 \\
\hline 7 & 7 & 49 & 132371 & 9 & 35,8525 & 26578065 \\
\hline
\end{tabular}

Tabel 8. Lanjutan perhitungan estimasi Metode trend eksponensial

\begin{tabular}{|c|c|c|c|c|c|c|}
\hline Periode & $\mathrm{t}$ & $\mathrm{t}^{\wedge} 2$ & $\mathrm{y}$ & $\begin{array}{c}\text { Log } \\
\mathrm{y}\end{array}$ & $\begin{array}{c}\mathrm{t}^{*} \log \\
\mathrm{y}\end{array}$ & $\mathrm{y}^{\prime}$ \\
\hline 8 & 8 & 64 & 198561 & 5,2978 & 42,383 & 1154227 \\
\hline 9 & 9 & 81 & 175269 & 5,2437 & 47,193 & 2287534 \\
\hline 10 & 10 & 100 & 172621 & 5,2370 & 52,370 & 4533609 \\
\hline 11 & 11 & 121 & 148763 & 5,1724 & 56,897 & 8985051 \\
\hline 12 & 12 & 144 & 130458 & 5,1154 & 61,385 & 17807256 \\
\hline 13 & 13 & 169 & 129869 & 5,1135 & 66,475 & 35291775 \\
\hline 14 & 14 & 196 & 180051 & 5,2554 & 73,575 & 69943923 \\
\hline 15 & 15 & 225 & 174927 & 5,2428 & 78,642 & 138620185 \\
\hline 16 & 16 & 256 & 145321 & 5,1623 & 82,597 & 274728023 \\
\hline 17 & 17 & 289 & 186678 & 5,2710 & 89,608 & 544476885 \\
\hline 18 & 18 & 324 & 130148 & 5,1144 & 92,059 & 1079085694 \\
\hline 19 & 19 & 361 & 173230 & 5,2386 & 99,533 & 2138614082 \\
\hline 20 & 20 & 400 & 210716 & 5,3237 & 106,47 & 4238468009 \\
\hline 21 & 21 & 441 & 161014 & 5,2068 & 109,34 & 8400118194 \\
\hline 22 & 22 & 484 & 146705 & 5,1664 & 113,66 & 1664799298 \\
\hline 23 & 23 & 529 & 153224 & 5,1853 & 119,26 & 3299425841 \\
\hline 24 & 24 & 576 & 128549 & 5,1090 & 122,61 & 6539053022 \\
\hline Total & 272 & 4760 & 274610 & 88,456 & 1414,0 & \multicolumn{1}{|c}{} \\
\cline { 1 - 2 } & & & & & &
\end{tabular}


Kemudian selanjutnya menghitung rata-rata kuadrat kesalahan ( Mean square error $=\mathrm{MSE}$ ) pada estimasi metode trend eksponensial sebagai berikut:

Tabel 9. Perhitungan galat metode estimasi Eksponensial

\begin{tabular}{|c|c|c|c|c|}
\hline $\mathrm{t}$ & $\mathrm{Y}$ & $\mathrm{y}^{\prime}$ & $\mathrm{E}$ & $\mathrm{e}^{\wedge} 2$ \\
\hline 1 & 172602 & 327880 & -155278 & 24111160986 \\
\hline 2 & 143826 & 682102 & -538276 & 289741054205 \\
\hline 3 & 178201 & 1419006 & -1240805 & 1539596243515 \\
\hline 4 & 132341 & 2952018 & -2819677 & 7950576074232 \\
\hline 5 & 176316 & 6141207 & -5964891 & 35579926865337 \\
\hline 6 & 141267 & 12775813 & -12634546 & 159631761176291 \\
\hline 7 & 132371 & 26578065 & -26445694 & 699374754212102 \\
\hline 8 & 198561 & 55291475 & -55092914 & 3035229160309980 \\
\hline 9 & 175269 & 115025196 & -114849927 & 13190505808221200 \\
\hline 10 & 172621 & 239291786 & -239119165 & 57177975204624500 \\
\hline 11 & 148763 & 497808835 & -497660072 & 247665547260401000 \\
\hline 12 & 130458 & 1035612797 & -1035482339 & 1072223675349750000 \\
\hline
\end{tabular}

Tabel 10. Lanjutan perhitungan galat metode estimasi eksponensial

\begin{tabular}{|c|c|c|c|c|}
\hline t & y & $\mathrm{y}^{\prime}$ & $\mathrm{E}$ & $e^{\wedge} 2$ \\
\hline 13 & 129869 & 2154429152 & -2154299283 & 4641005401060480000 \\
\hline 14 & 180051 & 4481950187 & -4481770136 & 20086263552314900000 \\
\hline 15 & 174927 & 9323990747 & -9323815820 & 86933541446164000000 \\
\hline 16 & 145321 & 19397092744 & -19396947423 & 376241569321868000000 \\
\hline 17 & 186678 & 40352593339 & -40352406661 & 1628316723320710000000 \\
\hline 18 & 130148 & 83947208516 & -83947078368 & 7047111966548160000000 \\
\hline 19 & 173230 & $\begin{array}{c}17463893233 \\
5\end{array}$ & -174638759105 & $\begin{array}{c}3049869618184440000000 \\
0\end{array}$ \\
\hline 20 & 210716 & $\begin{array}{c}36330876542 \\
9\end{array}$ & -363308554713 & $\begin{array}{c}1319931059277010000000 \\
00\end{array}$ \\
\hline 21 & 161014 & $\begin{array}{c}75580660779 \\
7\end{array}$ & -755806446783 & $\begin{array}{c}5712433849983210000000 \\
00\end{array}$ \\
\hline 22 & 146705 & $\begin{array}{c}15723364882 \\
61 \\
\end{array}$ & -1572336341556 & $\begin{array}{c}2472241570977710000000 \\
000\end{array}$ \\
\hline 23 & 153224 & \begin{tabular}{|c|}
32709981717 \\
73 \\
\end{tabular} & -3270998018549 & $\begin{array}{c}1069942803735070000000 \\
0000\end{array}$ \\
\hline 24 & 128549 & \begin{tabular}{|c|}
68047959960 \\
37 \\
\end{tabular} & -6804795867488 & $\begin{array}{c}4630524679818350000000 \\
0000 \\
\end{array}$ \\
\hline & & & & $\begin{array}{r}6021981492468930000000 \\
0000\end{array}$ \\
\hline
\end{tabular}

Dari tabel perhitungan galat di atas diperoleh lah nilai MSE untuk estimasi metode trend eksponensial yaitu 2.509.159.013.286.940.000.000.000. Sedangkan MSE untuk metode trend linear sebelumnya diketahui 544.291.863 dan MSE untuk metode trend kuadratik yaitu 14.333.867.566.980. Sehingga dapat diketahui bahwa nilai MSE terkecil yaitu metode trend linear. MSE yang kecil akan lebih baik dipilih karena akan semakin kecil pula perbedaan antara hasil estimasi dan data aktual. sehingga metode trend linear merupakan metode yang sementara dipilih untuk pengolahan selanjutnya.

\section{Pengujian Verifikasi Hasil Estimasi Terpilih}

Langkah selanjutnya dalam menentukan metode estimasi terbaik adalah dengan melakukan pengujian verifikasi (pemeriksaan) dengan menggunakan peta moving range untuk membandingkan nilai permintaan actual dengan nilai estimasi. Rumus perhitungan peta Moving Range adalah sebagai berikut.

$$
\begin{array}{rr}
\mathrm{BKA}=2,66 \times \overline{\mathrm{MR}} & |\mathrm{MR}=|\left(\mathrm{F}_{\mathrm{t}-1}-\mathrm{A}_{\mathrm{t}-1}\right)-\left(\mathrm{F}_{\mathrm{t}}-\mathrm{A}_{\mathrm{t}}\right) \mid \\
\mathrm{BKB}=-2,66 \times \overline{\mathrm{MR}} & \overline{\overline{M R}=\frac{\sum \mathrm{MR}}{\mathrm{n}-1}} \\
\mathrm{BKA}=2,66 \times \overline{\mathrm{MR}} & \mathrm{MR}=\left|\left(\mathrm{F}_{\mathrm{t}-1}-\mathrm{A}_{\mathrm{t}-1}\right)-\left(\mathrm{F}_{\mathrm{t}}-\mathrm{A}_{\mathrm{t}}\right)\right| \\
\mathrm{BKB}=-2,66 \times \overline{\mathrm{MR}} & \overline{\mathrm{MR}}=\frac{\sum \mathrm{MR}}{\mathrm{n}-1}
\end{array}
$$

Keterangan :

MR = Jarak atau range bergerak antara satu titik data dengan titik data sebelumnya $\mathrm{F}=$ Hasil estimasi $\mathrm{A}=$

Data aktual

$\mathrm{BKA}=$ Batas kendali atas $\mathrm{BKB}=$

Batas kendali bawah

Berikut perhitungan dengan menggunakan tabel

\begin{tabular}{|c|c|c|c|c|}
\hline periode & aktual & Forecast $\left(y^{\prime}\right)$ & $z=y-y^{\prime}$ & Moving Range \\
\hline 1 & 172602 & 160450,6133 & 12151,38667 & 12151,38667 \\
\hline 2 & 143826 & 160349,9368 & $\begin{array}{c}- \\
16523,93681 \\
\end{array}$ & 16523,93681 \\
\hline 3 & 178201 & 160249,2603 & 17951,73971 & 17951,73971 \\
\hline 4 & 132341 & 160148,5838 & $\begin{array}{c}- \\
27807,58377\end{array}$ & 27807,58377 \\
\hline 5 & 176316 & 160047,9072 & 16268,09275 & 16268,09275 \\
\hline 6 & 141267 & 159947,2307 & \begin{tabular}{c|}
- \\
18680,23072
\end{tabular} & 18680,23072 \\
\hline 7 & 132371 & 159846,5542 & $-27475,5542$ & 27475,5542 \\
\hline 8 & 198561 & 159745,8777 & 38815,12232 & 38815,12232 \\
\hline 9 & 175269 & 159645,2012 & 15623,79884 & 15623,79884 \\
\hline 10 & 172621 & 159544,5246 & 13076,47536 & 13076,47536 \\
\hline 11 & 148763 & 159443,8481 & 10680,84812 & 10680,84812 \\
\hline 12 & 130458 & 159343,1716 & $\begin{array}{c}- \\
28885,17159 \\
\end{array}$ & 28885,17159 \\
\hline 13 & 129869 & 159242,4951 & 29373,49507 & 29373,49507 \\
\hline 14 & 180051 & 159141,8186 & 20909,18145 & 20909,18145 \\
\hline
\end{tabular}
untuk mencari moving range:

Tabel 11. Perhitungan moving range trend Linier 


\begin{tabular}{|c|c|c|c|c|}
\hline 15 & 174927 & 159041,142 & |15885,85797 & 15885,85797 \\
\hline 16 & 145321 & 158940,4655 & 13619,46551 & 13619,46551 \\
\hline 17 & 186678 & 158839,789 & 27838,21101 & 27838,21101 \\
\hline 18 & 130148 & 158739,1125 & 28591,11246 & 28591,11246 \\
\hline 19 & 173230 & 158638,4359 & 14591,56406 & 14591,56406 \\
\hline 20 & 210716 & 158537,7594 & 52178,24058 & 52178,24058 \\
\hline 21 & 161014 & 158437,0829 & 2576,917101 & 2576,917101 \\
\hline 22 & 146705 & 158336,4064 & $\begin{array}{c}- \\
11631,40638\end{array}$ & 11631,40638 \\
\hline 23 & 153224 & 158235,7299 & 5011,729855 & 5011,729855 \\
\hline 24 & 128549 & 158135,0533 & $\begin{array}{c}- \\
29586,05333\end{array}$ & 29586,05333 \\
\hline$\overline{\Gamma o t a}$ & & & & 495733 \\
\hline
\end{tabular}

Dengan diperolehnya nilai- nilai dan batas-batas untuk uji verifikasi, maka nilai moving range dapat digambarkan kedalam bentuk grafik dibawah ini:

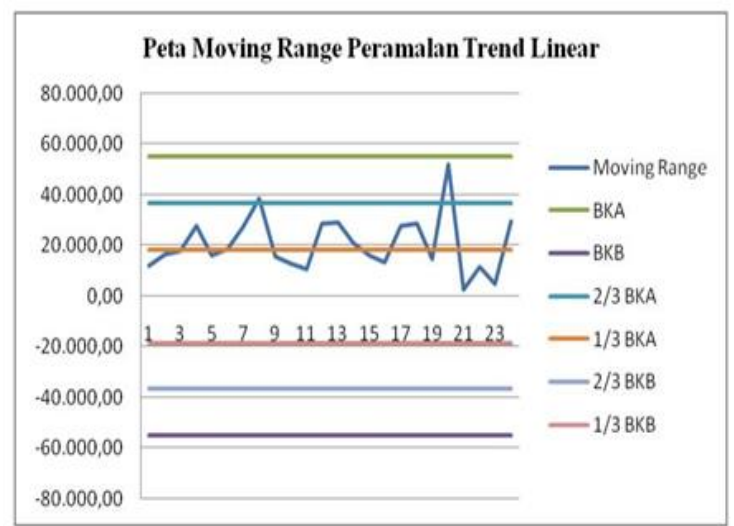

Gambar 1. Peta Moving Range Estimasi Trend Linier

Grafik yang ada diatas digunakan untuk uji kelengkapan data, apakah data yang kita gunakan dalam melakukan estimasi sudah terpenuhi atau belum. Data yang sudah lengkap bisa dilihat pada grafik diatas, dimana datanya tidak ada yang melewati batas kendali baik batas kendali atas maupun batas kendali bawah. Selanjutnya data yang sudah lengkap bisa digunakan untuk melakukan estimasi 1 tahun kedepan.

\section{Perhitungan Estimasi Untuk Tahun 2018}

Setelah dilakukan perhitungan dan uji verifikasi seperti di atas maka dipilihlah metode trend linier untuk dilakukan perhitungan estimasi untuk tahun 2018 dengan menggunakan rumus:

$\mathrm{y}(\mathrm{t})=160551,2899+(-100,676522) \mathrm{t}$

Sehingga didapat data permintaan konsumen ayia cup $240 \mathrm{ml}$ di PT. Gunung Naga Mas dapat dilihat pada tabel berikut:
Tabel 12. Data estimasi permintaan konsumen Ayia cup $240 \mathrm{ml}$ berdasarkan metode Trend linier

\begin{tabular}{|c|c|c|c|c|}
\hline \multirow[b]{2}{*}{ No } & \multirow[b]{2}{*}{ Periode } & \multirow[b]{2}{*}{ Bulan } & Ramalan Permintaan & \multirow[b]{2}{*}{ Roundup } \\
\hline & & & & \\
\hline 1 & 25 & Januari & 160450,6133 & 160451 \\
\hline 2 & 26 & Februari & 160349,9368 & 160350 \\
\hline 3 & 27 & Maret & 160249,2603 & 160250 \\
\hline 4 & 28 & April & 160148,5838 & 160149 \\
\hline 5 & 29 & Mei & 160047,9072 & 160048 \\
\hline 6 & 30 & Juni & 159947,2307 & 159948 \\
\hline 7 & 31 & Juli & 159846,5542 & 159847 \\
\hline 8 & 32 & Agustus & 159745,8777 & 159746 \\
\hline 9 & 33 & September & 159645,2012 & 159646 \\
\hline 10 & 34 & Oktober & 159544,5246 & 159545 \\
\hline 11 & 35 & November & 159443,8481 & 159444 \\
\hline 12 & 36 & Desember & 159343,1716 & 159344 \\
\hline & & & Total & 1918768 \\
\hline
\end{tabular}

\section{KESIMPULAN}

a. Pengolahan data permintaan konsumen dilakukan dengan menggunakan pendekatan estimasi dengan tujuan untuk mengetahui pergerakan permintaan konsumen dimasa atau periode yang akan datang. Dengan membandingkan tiga metode estimasi yang dilakukan dengan menghitung nilai Mean Square Error (MSE) yang terkecil dari metode trend linier, trend kuadratik, dan trend eksponensial, maka didapat kesimpulan bahwa metode yang paling cocok untuk menggambarkan fungsi permintaan ayia cup $240 \mathrm{ml}$ di PT. Gunung Naga Mas adalah metode trend linier dengan nilai MSE sebesar 544.291.863. Kemudian metode estimasi trend linier yang dipilih tersebut dilakukan uji verifikasi dengan menggunakan peta Moving Range (MR). Dari peta moving range yang dibuat diketahui bahwa hasil nilai estimasi untuk tingkat permintaan ayia cup $240 \mathrm{ml}$ berada di dalam peta kendali, sehingga nilai estimasi yang terpilih ini dapat digunakan oeh perusahaan untuk memperhitungkan permintaan konsumen dimasa yang akan datang.

b. Dari hasil perhitungan estimasi permintaan bahwa permintaan akan produk Ayia cup $240 \mathrm{ml}$ selama tahun 2018 mengalami kecenderungan penurunan permintaan setiap bulannya akan tetapi secara keseluruhan total permintaan pada tahun 2018 apabila dibandingkan dengan permintaan pada tahun sebelumnya terjadi peningkatan yang signifikan, Pada bulan Januari sebesar 160.451 dus, Februari sebesar 160.350 dus, Maret sebesar 160.250 dus, April sebesar 
160.149 dus, Mei sebesar 160.048 dus, Juni sebesar 159.948 dus, Juli sebesar 159.847 dus, Agustus sebesar 159.746 dus, September sebesar 159.746 dus, Oktober sebesar 159.545 dus, November sebesar 159.444 dus, dan Desember sebesar 159.344 dus. Sehingga total Ayia cup $240 \mathrm{ml}$ yang harus di produksi yaitu 1.918.768 dus.

\section{DAftar Pustaka}

[1] Assauri, S. Manajemen Operasi Produksi. PT Raja Grafindo Persada. Jakarta.2016

[2] Gaspersz Vincent. Production Planning and Inventory Control. PT. Sun. Jakarta. 1998.

[3] Handoko, T. Hani. Manajemen Sumber Daya Manusia. BPFE. Yogyakarta. 2000.

[4] Heizer, J. dan Render, B. Operations Management. Tenth Edition. Pearson, New Jersey. USA. 2011.

[5] Kusuma, Budhi Santri. Analisa Peramalan Permintaan Air Minum Dalam Kemasan Pada PT. XYZ Dengan Metode Least Square dan Standard Error of Estimate. MIEJ Journal. Medan. 2015.

[6] Kusuma, Hendra. Manajemen Produksi: Perencanaan dan Pengendalian Produksi. Edisi 4.Yogyakarta. 2009.

[7] Mulyono.Peramalan Bisnisdan Ekonometrika. Edisi Pertama. BPFE. Yogyakarta. 2000.I

[8] Nafarin, M. Penganggaran Perusahaan. Edisi Ketiga. Salemba Empat. Jakarta. 2007.

[9] Nugraha, Eucharistia Yacoba dan I Wayan Suletra. Analisis Metode Peramalan Permintaan Terbaik Produk Oxycan pada PT. SamatorGresik. Jurnal Universitas Sebelas Maret. Surakarta. 2017.

[10] Nasution, AH. Manajemen Industri. Andi Offset. Yogyakarta. 2006.

[11] Nazir, Moh. Metode Penelitian. Ghalia Indonesia. Jakarta. 2005.

[12] Heizer, J. Dan Render B. Manajemen Operasi (Terjemahan). Salemba empat. Jakarta. 2013.

[13] Rangkuti,F. Manajemen Persediaan Aplikasi di Bidang Bisnis. Erlangga. Jakarta. 2004.

[14] Subagyo, Pangestu. Forecasting Konsep dan aplikasi . BPPE UGM. Yogyakarta. 1986.
[15] Sudjarwo dan Basrowi. Manajemen Penelitian Sosial. CV. Mandar Maju. Bandung. 2009.

[16] Yamit, Zulian. Manajemen Persediaan. CV. Adipura. Yogyakarta. 2005. 